\title{
RANCANG BANGUN SISTEM APLIKASI PENENTUAN SISWA BERPRESTASI PADA SISTEM INFORMASI AKADEMIK DI SMP NEGERI 1 SANGKAPURA GRESIK
}

\author{
Afif Amrullah ${ }^{1}$, Ely Setyo Astuti ${ }^{2}$, Budi Harijanto. ${ }^{3}$ \\ ${ }^{1}$ Program Studi Teknik Informatika, ${ }^{2}$ Jurusan Teknik Elektro, ${ }^{3}$ Politeknik Negeri Malang \\ 19afifamrullah8@gmail.com, ${ }^{2}$ nugelys2005@yahoo.com, ${ }^{3}$ budi.harijnto@polinema.co.id.
}

\begin{abstract}
Abstrak
Dunia pendidikan memegang peranan penting dalam kemajuan suatu bangsa. Kemajuan dunia pendidikan dapat dilihat dari banyaknya siswa yang berprestasi. Siswa berprestasi merupakan ukuran keberhasilan yang diperoleh seseorang atau siswa selama proses kegiatan belajar. Dalam pencapaian siswa berprestasi harus ada peranan dan kontribusi dari berbagai pihak seperti pemerintah maupun sekolah. Maka dibuatlah sebuah sistem aplikasi penentuan siswa berprestasi pada sistem informasi akademik di SMP Negeri 1 Sangkapura untuk mencari siswa terbaik berdasarkan kriteria-kriteria yang telah ditentukan menggunakan metode SAW (Simple Additive Weighting). Kriteria-kriteria yang dipilih yaitu rata-rata nilai pengetahuan, ratarata nilai keterampilan, rata-rata nilai sikap dan rata-rata nilai ekstrakulikuler yang diambil dari nilai raport. Setelah itu dilakukan proses penentuan ranking untuk menentukan alternatife yang optimal yaitu siswa berprestasi. Berdasarkan hasil uji coba yang dilakukan oleh pihak sekolah, Sistem Aplikasi Penentuan Siswa Berprestasi telah berhasil menerapkan perhitungan nilai dalam menentukan siswa berprestasi dengan hasil yang didapatkan yaitu ranking siswa berprestasi.
\end{abstract}

Kata kunci : Siswa Berprestasi, $S A W$.

\section{Pendahuluan}

\subsection{Latar Belakang}

Dunia pendidikan memegang peranan penting dalam kemajuan suatu bangsa. Kemajuan dunia pendidikan dapat dilihat dari banyaknya siswa yang berprestasi. Siswa berprestasi merupakan ukuran keberhasilan yang diperoleh seseorang atau siswa selama proses kegiatan belajar. Keberhasilan itu ditentukan oleh beberapa faktor tidak hanya berprestasi dari bidang akademik saja tetapi juga berprestasi dibidang lainnya seperti di kegiatan ekstrakulikuler. Dalam pencapaian tersebut harus ada peranan dan kontribusi dari berbagai pihak, baik dari pihak sekolah, pemerintah, swasta, masyarakat maupun orang tua. Terutama guru dan orang tua sangat berperan penting dalam pencapaian prestasi siswa. Dengan adanya penilaian hasil belajar, guru dapat mengetahui seberapa besar pencapaian siswa dalam memahami suatu materi pembelajaran secara keseluruhan, sehingga guru dapat memberikan motivasi dan menentukan langkah yang akan dilakukan terhadap siswa-siswinya. Maka untuk memenuhi pencapaian tersebut dibuatlah sebuah sistem aplikasi penentuan siswa berprestasi untuk mengetahui peringkat atau prestasi yang telah dicapai oleh siswa serta melakukan pengukuran.
Untuk melakukan pengukuran prestasi siswa, maka dibuatlah sebuah sistem aplikasi penentuan siswa berprestasi. Sistem aplikasi penentuan siswa berprestasi adalah bagian dari sistem informasi berbasis komputer yang mengelolah data menjadi informasi untuk membantu dan menunjang berbagai bentuk proses dalam menentukan siswa berprestasi. Penentuan siswa berprestasi tidak hanya di ambil dari nilai kognitif, efektif dan psikomotorik saja, tetapi juga dari nilai ekstrakulikuler. Pengambilan penilaian tersebut di ambil dari rata-rata nilai rapot siswa sesuai dengan kurikulum yang berlaku saat ini yaitu kurikulum 2013. Proses penentuan siswa berprestasi haruslah benar-benar sesuai dengan penilaian hasil belajar siswa, yang nantinya menjadi tolak ukur pemahaman siswa. Sehingga dengan penentuan peringkat tersebut, siswa diharapkan termotivasi untuk belajar lebih baik, lebih terampil dan lebih aktif lagi baik di dalam maupun di luar kelas.

Untuk menunjang sebuah sistem aplikasi siswa berprestasi perlu adanya sebuah metode yang dipakai. Metode yang akan digunakan adalah Metode Simple Additive Weighting (SAW). Menurut Kusumadewi (2007), metode SAW sering juga dikenal dengan istilah metode penjumlahan terbobot. Konsep dasar metode SAW adalah 
mencari penjumlahan terbobot dari rating kinerja pada setiap alternatif pada semua atribut.

Sehingga penulis merasa tertarik untuk mengamati dan melakukan analisa dengan mengambil judul "Rancang Bangun Sistem Aplikasi Penentuan Siswa Berprestasi Pada Sistem Informasi Akademik di SMP Negeri 1 Sangkapura Gresik".

\subsection{Rumusan Masalah}

Dari latar belakang tersebut maka dapat dirumuskan permasalahan yang ada, diantaranya :

1) Bagaimana cara pengukuran hasil pembelajaran siswa dalam menentukan siswa berprestasi?

2) Bagaimana cara membangun sebuah sistem aplikasi dalam menentukan siswa yang berprestasi, baik dari segi kognitif, efektif, psikomotorik dan di kegiatan ekstrakurikuler?

3) Bagaimana cara memformulasikan dan pembobotan nilai siswa kedalam sistem aplikasi penentuan siswa berprestasi dengan menggunakan Metode Simple Additive Weighting $(S A W)$ ?

4) Bagaimana cara menerapkan sistem aplikasi penentuan siswa berprestasi kedalam sistem informasi akademik sekolah?

\subsection{Batasan Masalah}

Sistem aplikasi penentuan siswa berprestasi pada sistem informasi akademik sekolah di SMP Negeri 1 Sangkapura ini dibuat bertujuan untuk menentukan peringkat atau prestasi siswa. Karena luasnya cakupan perumusan masalah yang penulis teliti, maka penulis membuat batasanbatasan masalah, antara lain :

1) Rancang Bangun Sistem Informasi Akademik Siswa Berprestasi di SMP Negeri 1 Sangkapura ini menggunakan Metode Simple Additive Weighting (SAW).

2) Penentuan prestasi siswa di ambil dari nilai rata-rata kognitif, efektif, psikomotorik dan kegiatan ekstrakurikuler berdasarkan format rapot kurikulum 2013.

3) Dalam perancangan sistem informasi akademik ini menggunakan bahasa pemrograman PHP dan MySQL sebagai database karena lebih memudahkan bagi siswa/wali murid dalam mengakses informasi seputar sekolah.

\subsection{Tujuan Penelitian}

Adapun tujuan dari adanya pembuatan sistem aplikasi penentuan siswa berprestasi pada sistem informasi akademik ini yaitu untuk mendukung proses perhitungan nilai siswa dalam menentukan siswa yang berprestasi di SMP Negeri 1 Sangkapura.

\section{Metode}

\subsection{Metode SAW (Simple Additive Weighting)}

Merupakan metode penjumlahan terbobot. Konsep dasar metode SAW adalah mencari penjumlahan terbobot dari rating kinerja pada setiap alternatif pada semua atribut. Metode SAW membutuhkan proses normalisasi matriks keputusan (x) ke suatu skala yang dapat diperbandingkan dengan semua rating alternatif yang ada. Skor total untuk alternatif diperoleh dengan menjumlahkan seluruh hasil perkalian antara rating (yang dapat dibandingkan lintas atribut) dan bobot tiap atribut. Rating tiap atribut haruslah bebas dimensi dalam arti telah melewati proses normalisasi matriks sebelumnya. Metode saw mengenal adanya 2(dua) atribut yaitu criteria keuntungan (benefit) dan criteria biaya (cost). Perbedaan mendasar dari kedua criteria ini adalah dalam pemilihan criteria ketika mengambil keputusan.

$$
\begin{aligned}
& r_{i j}=\left\{\begin{array}{l}
\frac{x_{i j}}{M a x_{i} x_{i j}} \text { Jika } \mathrm{j} \text { adalah atribut keuntungan (benefit) } \\
\frac{M n_{i} x_{i j}}{x_{i j}} \text { Jika } \mathrm{j} \text { adalah atribut biaya (cost) }
\end{array}\right. \\
& \mathrm{R}_{\mathrm{ij}} \quad=\text { Rating kinerja normalisasi } \\
& \operatorname{Max}_{\mathrm{i}} \quad=\text { Nilai maximum dari setiap baris dan }
\end{aligned}
$$
kolom

$\operatorname{Min}_{\mathrm{i}}=$ Nilai minimum dari setiap baris dan kolom

$\mathrm{x}_{\mathrm{ij}} \quad=$ Baris dan Kolom dari matriks

$\mathrm{R}_{\mathrm{ij}}$ adalah rating kinerja ternomalisasi dari alternative pada atribut $i=1,2, \ldots \mathrm{m}$ dan $\mathrm{j}=1,2, \ldots \mathrm{n}$.

Nilai preferensi untuk setiap alternative (Vi) diberikan sebagai:

$$
V_{i}=\sum_{j=i}^{n} w_{i} r_{i j}
$$

$\mathrm{V}_{\mathrm{i}}=$ rating untuk setiap alternatif

$\mathrm{W}_{\mathrm{j}}=$ nilai bobot dari setiap alternatif

$\mathrm{R}_{\mathrm{ij}}=$ nilai rating kinerja ternomalisasi

Nilai Vi yang lebih besar mengindikasikan bahwa alternative $\mathrm{A}_{\mathrm{i}}$ lebih terpilih.

Ada empat kriteria yang digunakan untuk melakukan penilaian siswa berprestasi, yaitu:

$\mathrm{C} 1$ = Rata-rata nilai Pengetahuan (wawasan)

$\mathrm{C} 2=$ Rata-rata nilai Keterampilan

C3 = Rata-rata nilai Sikap.

C4 = Rata-rata nilai Ekstrakurikuler 


\subsection{Metode Penelitian}

Berikut merupakan kerangka penelitian yang digunakan.

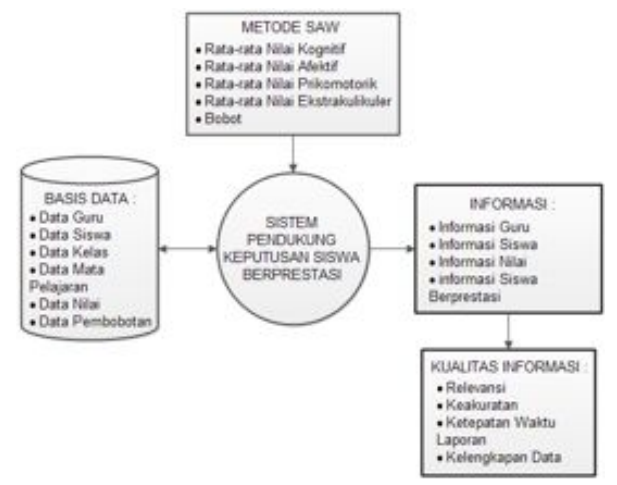

Gambar 2.1 Kerangka Konsep Penelitian

Sedangkan untuk pengembangan sistem aplikasi penentuan siswa berprestasi menggunakan metode $S A W$ (Simple Additive Weighting)

\section{Perancangan}

\subsection{Deskripsi Sistem}

Sistem aplikasi penentuan siswa berprestasi ini merupakan bagian dari sistem informasi akademik, dimana dalam menentukan siswa berprestasi diambil dari rata-rata nilai kognitif, prikomotorik, afektif dan ekstrakulikuler.

\subsection{Metode Perancangan}

Metode perancangan yang digunakan untuk pembuatan sistem aplikasi penentuan siswa berprestasi menggunakan metode prototype.

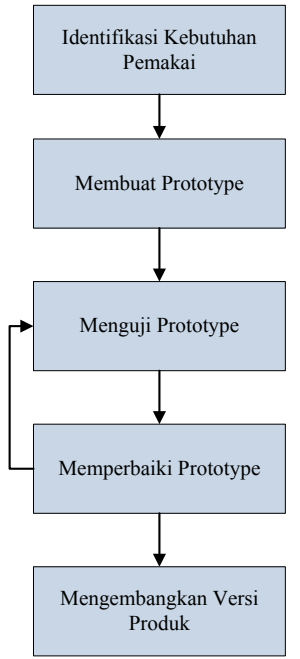

- Pengembang dan pemakai bertemu - Pemakai menjelaskan kebutuhan user

- Pengembang mulai membuat prototype

Pemakai menguji prototype dan Memberikan kritikan dan saran

Pengembang melakukan modifikasi sesuai dengan masukan dari pemakai

Pengembang merampungkan sistem sesuai dengan masukan terakhir

Gambar 3.1 Kerangka Tahapan Perancangan

Prototype dievaluasi oleh pemakai dan digunakan sebagai landasan untuk memperbaiki spesifikasi kebutuhan. Proses ini akan berulang

sampai prototype yang dikembangkan memenuhi seluruh kebutuhan pemakai.

\subsection{Analisis Kebutuhan Sistem}

Kebutuhan sistem yang dibutuhkan untuk membangun serta mengimplementasikan sebuah sistem aplikasi penentuan siswa berprestasi pada sistem informasi akademik sekolah yang memiliki penggunaan yang mudah dari sisi admin, kepala sekolah, guru dan siswa/wali murid.

\subsection{Desain Sistem}

Pada tahap ini dilakukan proses tranformasi dari analisis kebutuhan sistem kedalam model sistem yang nantinya akan dibangun.

- Logical Process Model

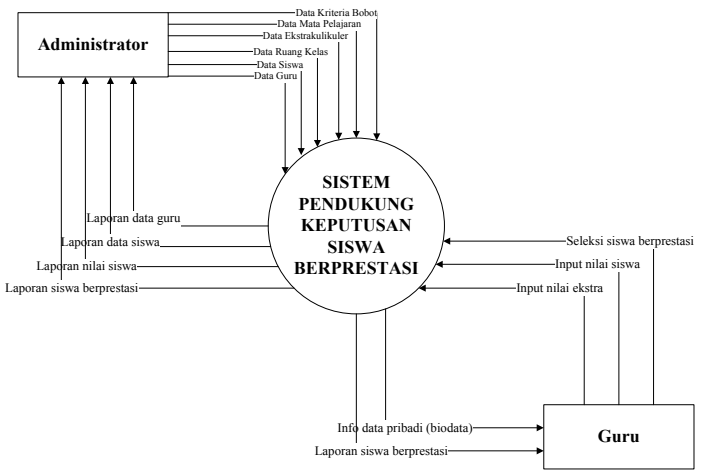

Gambar 3.2 Diagram Konteks

- Logical Interface Design

Logical interface design dibagi menjadi 2 bagian, yaitu:

Login Page

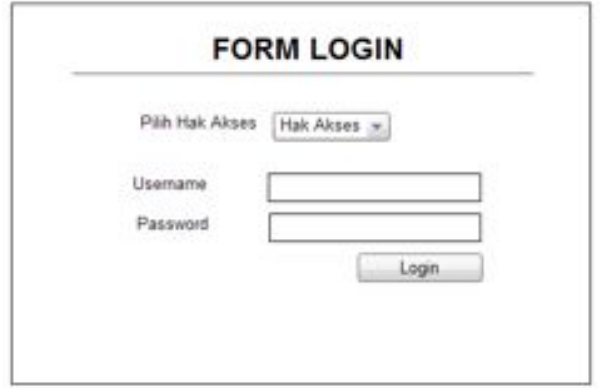

Gambar 3.3 Rancangan Login Page User Page 


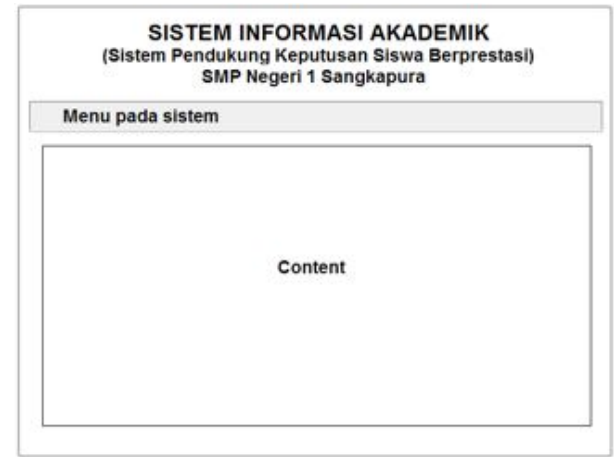

Gambar 3.4 Rancangan User Page

- Use Case Diagram

Penggunaan sistem apilkasi penentuan siswa berprestasi ada empat aktor yaitu: admin, kepala sekolah, guru dan siswa/wali murid.

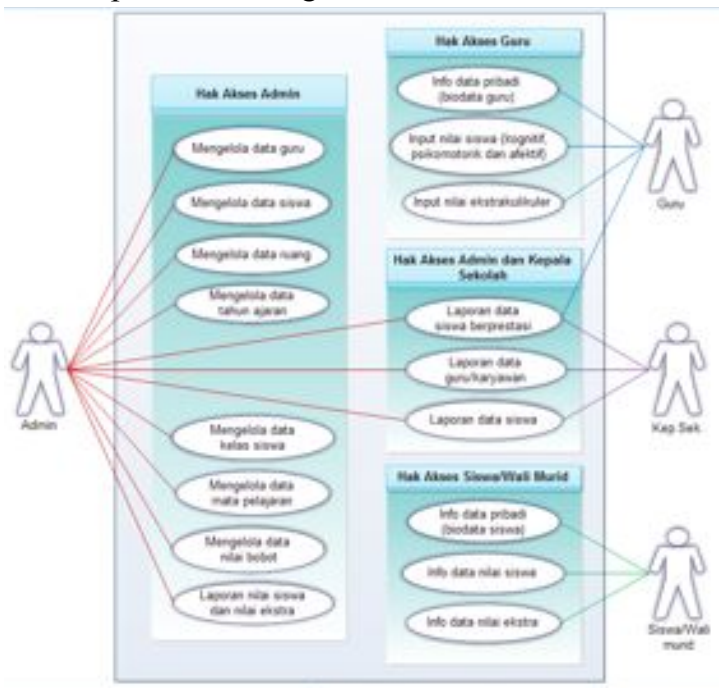

Gambar 3.5 Use Case Diagram

- Flowchart Sistem

Perancangan ini digunakan untuk menggambarkan alur suatu program menjadi lebih sederhana sehingga program tersebut lebih dapat dimengerti.

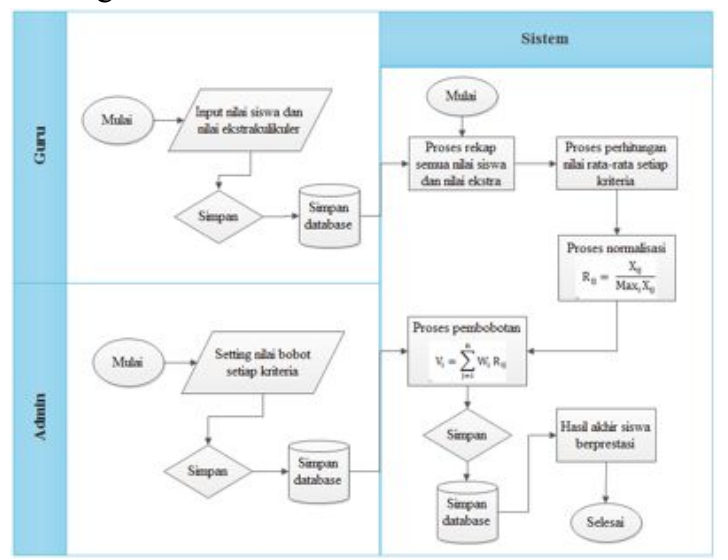

Gambar 3.6 Flowchart Penentuan siswa berprestasi

\section{Hasil}

Sistem yang sudah dihasilkan dari hasil penelitian memiliki 4 user yaitu administrator, kepala sekolah, guru dan siswa/wali murid. Tiap user memiliki hak akses yang berbeda-deba. Berikut merupakan beberapa tampilan sistem yang telah selesai dibuat.

\subsection{Login Page}

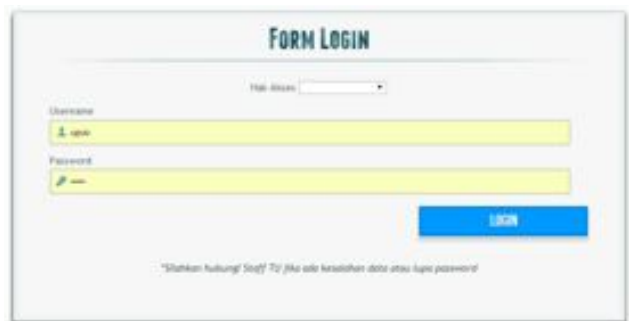

Gambar 4.1 Tampilan Login Page

\subsection{User Page}

- Menu Administrator

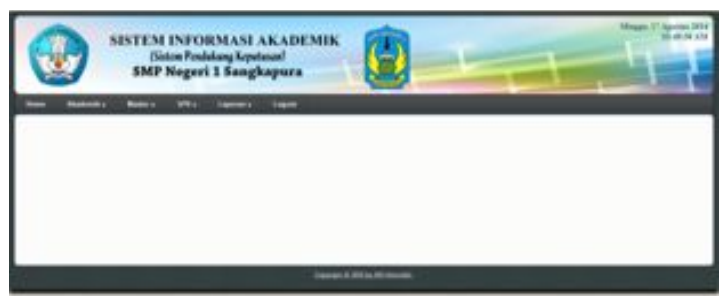

Gambar 4.2 Tampilan User Page Admin

- Menu Kepala Sekolah

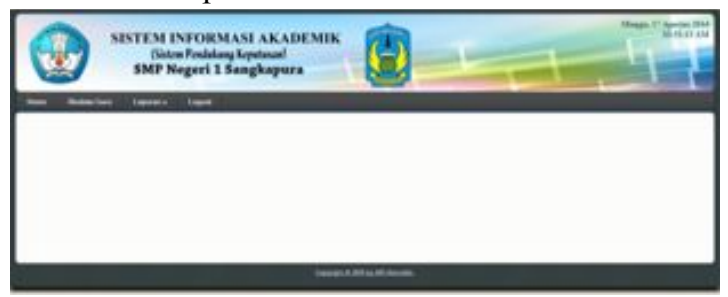

Gambar 4.3 Tampilan User Page Kepala Sekolah

- $\quad$ Menu Guru

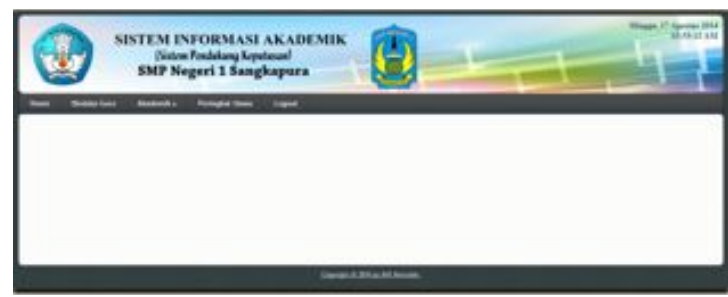

Gambar 4.4 Tampilan User Page Guru

- Menu Siswa/Wali Murid 


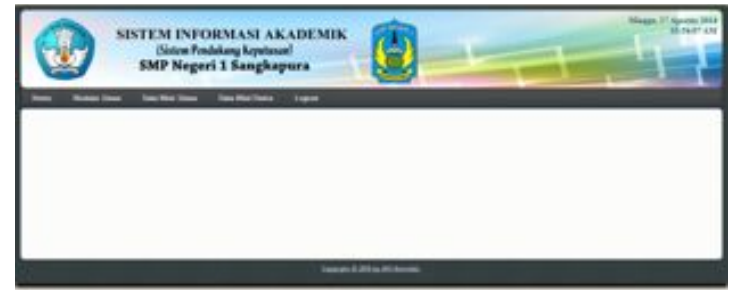

Gambar 4.5 Tampilan User Page Siswa/Wali Murid

\section{Pembahasan}

\subsection{Analisa Pengujian Sistem}

Berikut merupakan penilaian sistem aplikasi penentuan siswa berprestasi. Dalam menentukan siswa berprestasi kriteria-kriteria yang diambil yaitu rata-rata nilai pengetahuan, keterampilan, sikap dari setiap mata pelajaran dan rata-rata nilai ekstrakulikuler.

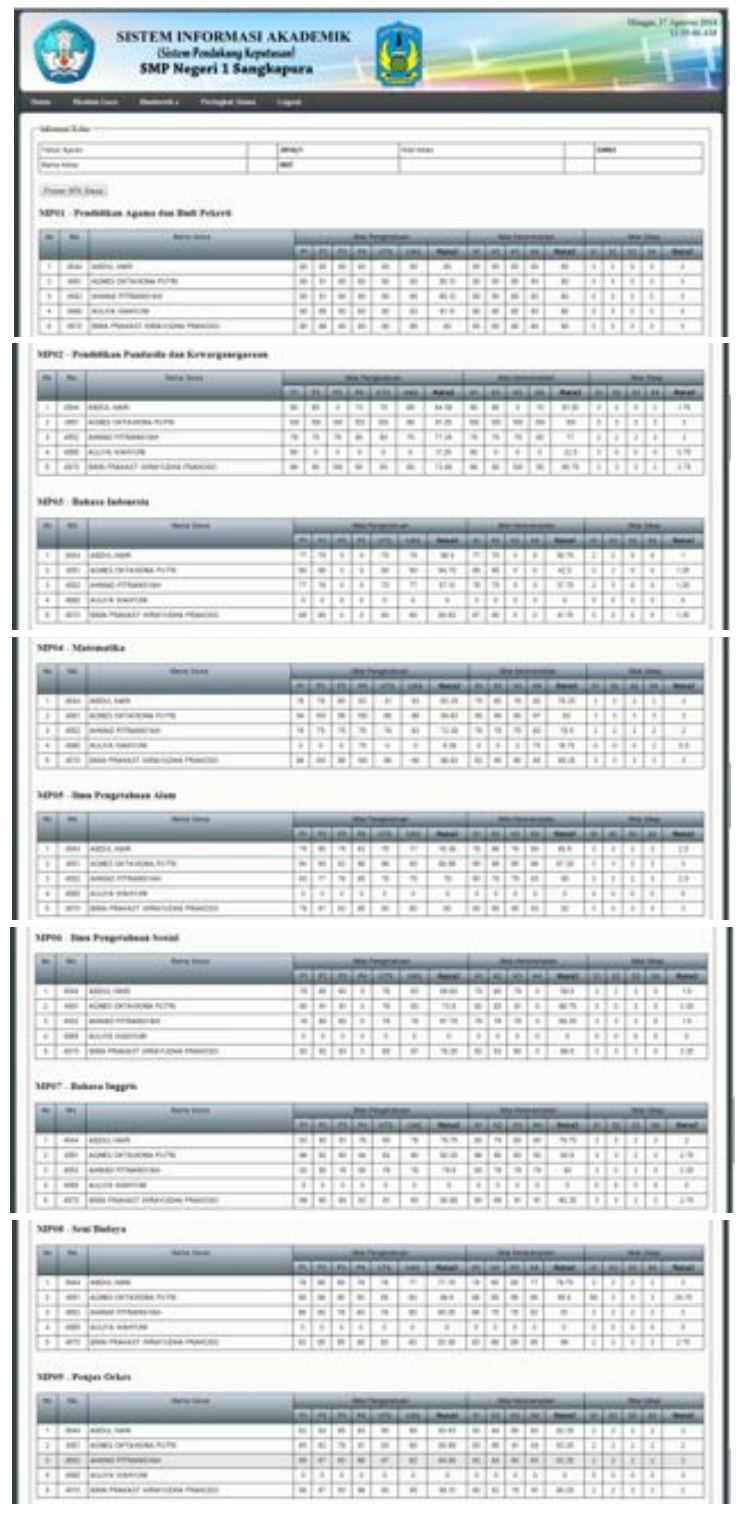

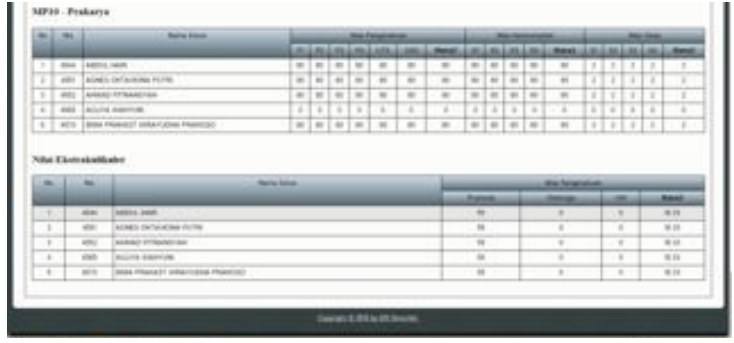

Gambar 5.1 Rekap Semua Nilai Siswa

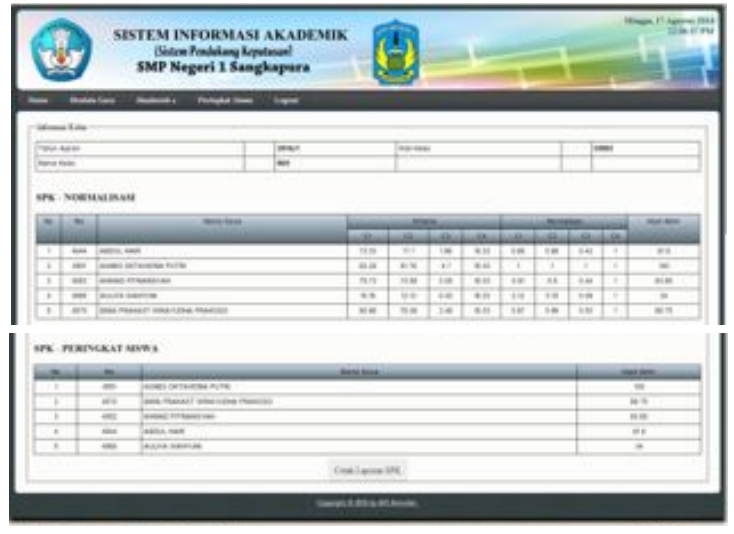

Gambar 5.2 Hasil Perangkingan Siswa Berprestasi

Pada Gambar 5.2 telah didapatkan hasil peringkat siswa atau siswa berprestasi, dimana nilai tertinggi diraih oleh Agnes Oktaviona Putri dengan nilai 100 .

\subsection{Analisa Pengujian Penggunaan}

Pengujian kegunaan dilakukan dengan melakukan uji coba kepada pemakai yaitu pihak sekolah baik dari sisi admin, kepala sekolah, guru dan siswa/wali murid. 

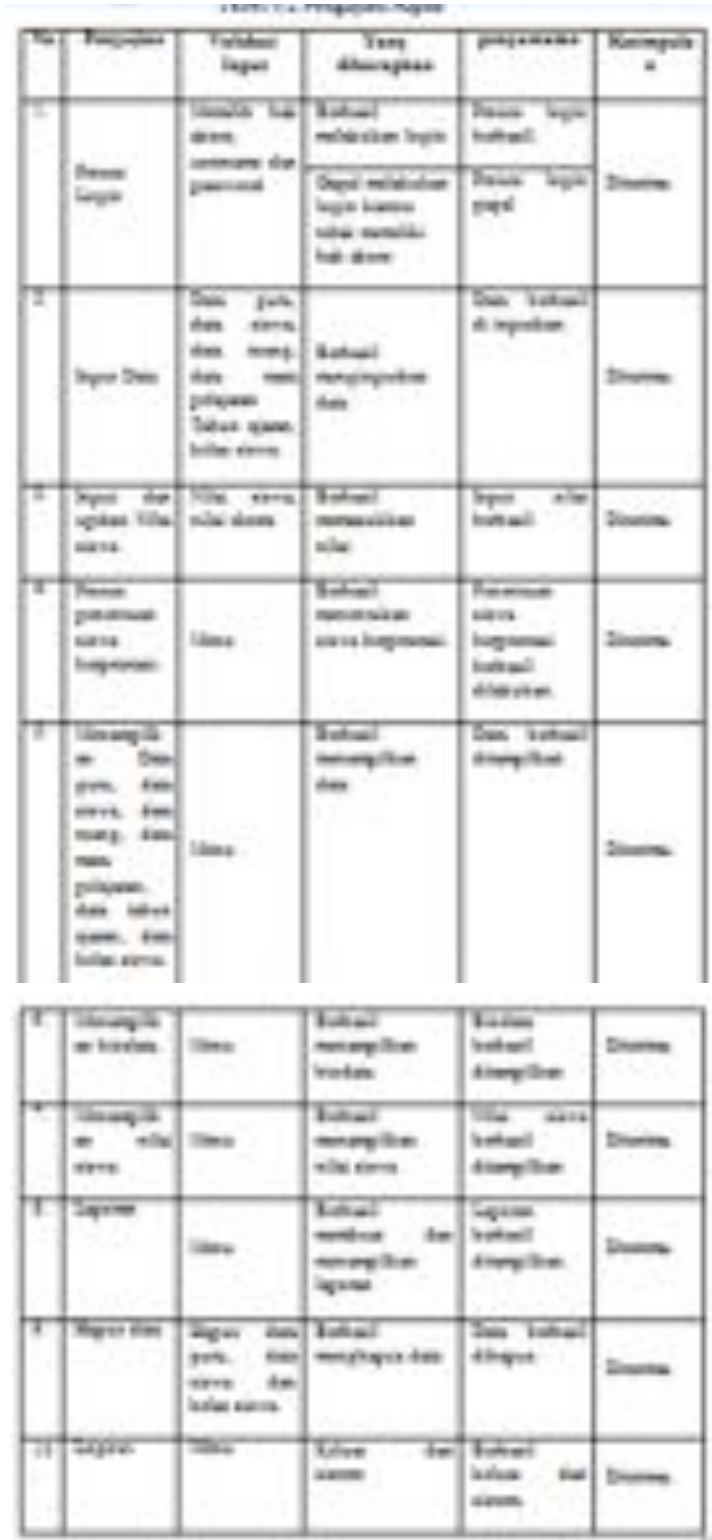

Gambar 5.3 Hasil Pengujian Pengguna

\section{Penutup}

\subsection{Kesimpulan}

Dari uraian yang telah dijelaskan pada bab-bab sebelumnya, maka dapat diambil kesimpulan mengenai Rancang Bangun Sistem pendukung Keputusan Siswa Berprestasi Pada Sistem Informasi Akademik di SMP Negeri 1 Sangkapura sebagai sarana penunjang dalam menentukan siswa berprestasi yaitu bahwa :

1. Aplikasi ini dapat mengola data nilai siswa, data nilai ekstrakulikuler siswa dan data-data penunjang lainnya seperti data guru, data siswa, data kelas, data mata pelajaran dan data kegiatan ekstrakulikuler.
2. Aplikasi ini dapat menentukan siswa berprestasi berdasarkan empat kriteria yang telah diambil, yaitu rata-rata nilai pengetahuan, rata-rata nilai keterampilan, rata-rata nilai sikap dan rata-rata dari nilai kegiatan ekstrakulikuler.

3. Aplikasi ini dapat mempermudah guru dalam penginputan nilai serta proses penentuan peringkat siswa/siswa berprestasi.

\subsection{Saran}

Saran yang dapat diberikan sebagai tindak lanjut dari hasil penelitian adalah sebagai berikut:

1. Aplikasi Sistem Pendukung Keputusan ini bisa dikembangkan lagi menjadi Sistem Informasi Akademik.

2. Kriteria yang digunakan dalam penentuan siswa berprestasi dapat di tambahkan misalnya absensi siswa sebagai kriteria yang kelima.

\section{Daftar Pustaka}

Abdul Kadir. : PENGENALAN SISTEM INFORMASI, 2003, Andi. Yogyakarta.

Data Pegawai, Data Siswa dan Transkip Nilai Siswa : SMP Negeri 1 Sangkapura, 2014.

Dr. Tedjo Narsoyo Reksoatmodjo, ST., M.Pd.: PENGEMBANGAN KURIKULUM PENDIDIKAN TEKNOLOGI DAN KEJUJURAN, 2010.

Edhy Sutanta.: BASIS DATA DALAM TINJAUAN KONSEPTUAL, penerbit andi, 2011.

Kusumadewi, Sri., Hartati, S., Harjoko, A., dan Wardoyo, R. (2006). Fuzzy Multi-Attribute Decision Making (FUZZY MADM), Penerbit Graha Ilmu. Yogyakarta

M. Rudyanto Arief:: PEMROGRAMAN WEB DINAMIS MENGGUNAKAN PHP DAN MYSQL, Penerbit Andi, 2011.

Nandang Hernanto : (2012). Seminar Nasional Teknologi Informasi \& Komunikasi Terapan 2012.

Roger S. Pressman, Ph.D.: REKAYASA PERANGKAT LUNAK, Penerbit Andi, Buku 1, Pendekatan Praktisi (Edisi 7), 2012

Stendy B. Sakur.: PHP 5 PEMROGRAMAN BERORIENTASI OBJEK (KONSEP DAN IMPLEMENTASI), penerbit Andi, 2010. 
Whitten, Jeffery L 2006, Systems Metode Desain dan Analisis Sistem edisi 6, Andi, Yogyakarta.

\section{Lampiran}

\section{Profil Penulis}

Afif Amrullah lahir pada tanggal 08 April 1992 di Gresik. Saat ini sedang menempuh pendidikan di Jurusan Teknik Elektro Program Studi Teknik Informatika Politeknik Negeri Malang. 